\title{
Synthesis and ESR studies of multiphenyl porphyrins
}

\author{
Fernando García-Álvarez ${ }^{1 *}{ }^{*}$, Guillermo L. Rodríguez-Acosta ${ }^{1}$ (D) , Virginia Gómez-Vidales ${ }^{1}$ (D), Simón \\ Hernández-Ortega ${ }^{1}$ (D), Marcos Martínez-García ${ }^{1, *(D)}$ \\ 1 Instituto de Química, Universidad Nacional Autónoma de México, Ciudad Universitaria, Circuito Exterior, Coyoacán, \\ CDMX. C.P. 04510, México \\ * Correspondence: fernando.garcia@iquimica.unam.mx (F.G.A.); margar@unam.mx (M.M.G.);
}

Scopus Author ID 55548578100

Received: 4.07.2021; Revised: 15.09.2021; Accepted: 20.09.2021; Published: 8.11.2021

\begin{abstract}
The synthesis of tetra biphenyl and tetra triphenyl derivatives of porphyrin has been achieved with relative ease, and although the compounds show the expected low solubility in organic solvents, their tendency to form aggregates was observed. They are sufficiently dispersed to allow characterization by ${ }^{1} \mathrm{H},{ }^{13} \mathrm{C}$, mass spectrometry, and determine their photophysical properties. The presence of 8 hydroxyl groups and 12 aromatic rings in the structure of the porphyrin showed to be able to stabilize the superoxide anion. This approach allows the possibility of using these compounds as building blocks and could be applicable to synthesizing other highly structurally uniform and welldefined porphyrin derivatives in good yields.
\end{abstract}

Keywords: porphyrin; polyphenyl; Suzuki-Miyaura coupling.

(C) 2020 by the authors. This article is an open-access article distributed under the terms and conditions of the Creative Commons Attribution (CC BY) license (https://creativecommons.org/licenses/by/4.0/).

\section{Introduction}

The synthesis of porphyrin derivatives with several meso-substituents is being carried out by many researchers to explore ways to introduce a great variety of donor substituents in the skeleton for use in areas such as molecular electronics [1-5] and photovoltaics [6-8]. One of these attempts involves obtaining porphyrins with an extended $\pi$-conjugation system that results in a wide range of wavelengths for light absorption. The high symmetry leads to excellent solid-state properties, especially in the meso-substituted poly-phenyl porphyrin derivatives [9-11] that show well-defined spatial arrangement: in general, they have planar shape points in a certain direction determined by their connectivity, which might aid in the electrical or mechanical transmission of energy, properties that are often at the heart of their function [12-15]. Porphyrins are very stable (chemically and thermally) and can obtain thin films of great quality. These properties make porphyrin derivatives an interesting material for the fabrication of electroluminescent devices [16], photonic devices [17], solar energy conversion devices [18], photodynamic therapy, diagnosis of cancer [19], catalysis [20], and photo-electro-chemical cells [21]. Here we report on preparing meso-derivatives of porphyrins with polyphenyl units joined directly to them using the Suzuki-Miyaura coupling. The porphyrins have been synthesized and fully characterized; their tendency to form aggregates has been studied, and their photochemical characteristics established. 


\section{Materials and Methods}

\subsection{Chemicals and reagents.}

Solvents and reagents were purchased as reagent grade and used without further purification. Toluene was distilled from sodium, and benzophenone and methanol were distilled over calcium oxide $(\mathrm{CaO})$ powder. Chromatographic columns were performed on Merck silica gel $60 \AA$ (70-230 mesh). ${ }^{1} \mathrm{H}$ - and ${ }^{13} \mathrm{C}$-NMR spectra were recorded on a Varian Unity-300 MHz instrument with tetramethylsilane (TMS) as an internal reference. Infrared (IR) spectra were measured on a Nicolet FT-SSX spectrophotometer. Matrix-assisted laser desorption ionization time-of-flight mass spectroscopy (MALDI-TOF-MS) was performed on a JEOL JMS AX505 HA instrument using 9-nitroanthracene (9NA) as a matrix. Elemental analysis was determined by Galbraith Laboratories, Inc. (Knoxville, TN, USA). The measurements by ESR were carried out at room temperature with a Jeol JES-TE300 spectrometer system operating at $\mathrm{X}$ band, $100 \mathrm{kHz}$ modulation frequency, and a cylindrical cavity in the mode $\mathrm{TE}_{011}$. The external calibration of the magnetic field was made with a precision gaussmeter Jeol ES-FC5. The spectrometer settings for all spectra were as follows: center field, $336.2 \pm 4 \mathrm{mT}$; microwave frequency, $9.43 \mathrm{GHz}$; modulation width, $0.04 \mathrm{mT}$; time constant, $0.1 \mathrm{~s}$; amplitude, 20. Spectral acquisition and manipulations were performed using the program ES-IPRITS/TE. The UV light irradiation of the samples was performed in situ for $20 \mathrm{~min}$, with a light illuminator OPS A500 (Oriel) equipped with a Hg lamp $200 \mathrm{~W}$ and an optical filter 10SWF-400-B. The UV-Vis absorption spectra were obtained at room temperature with a Shimadzu 2401 PC spectrophotometer, and a Perkin-Elmer LS-50 spectrofluorimeter was used for the fluorescence spectra. The excitation wavelengths used for the emission properties are presented in the text.

\subsection{Synthesis of porphyrins $3,4$.}

In a bottomed flask of $250 \mathrm{ml}$ equipped with a magnetic stirrer was added $(21.74 \mathrm{~mol})$ of $p$-bromobenzaldehyde, or 3,5-dibromonezaldehyde, $(21.74 \mathrm{~mol})$ of pyrrole and $25 \mathrm{ml}$ of propionic acid; the mixture was stirred and refluxed for 12 hours at $140^{\circ} \mathrm{C}$ under nitrogen atmosphere. After this time, the reaction mixture was cooled at room temperature, then $50 \mathrm{ml}$ of water was added. The crude reaction was filtered under a vacuum and washed with hot water. The solid was washed with methanol to obtain a purple solid.

5,10,15,50-(tetra-p-bromophenyl) porphyrin 3. $1.02 \mathrm{~g}(1.63 \mathrm{mmol})$, yield $30 \%$ of the m.p >300 ${ }^{\circ} \mathrm{C}$, UV-Vis $\mathrm{CHCl}_{3}(\mathrm{~nm}) ; 290,370,420,450,616,660$. FTIR KBr $\left(\mathrm{cm}^{-1}\right) ; 3313$, 1556, 1469, 1388, 1345, 1245, 1214, 1179, 1096, 1066, 1009, 985, 961, 873, 841, 749, 731, 709, 638, 553, 520, 449. ${ }^{1} \mathrm{H}$ NMR (300 MHz, $\left.\mathrm{CDCl}_{3}\right) \delta(\mathrm{ppm}):-2.85$ (br, 2H, NH), $7.90(\mathrm{~d}$, $8 \mathrm{H}, J=8.4 \mathrm{~Hz}, \mathrm{Ar}), 8.06$ (d, 8H, J= 8.1 Hz, Ar), 8.84 (s, 8H, Py). ${ }^{13} \mathrm{C}$ NMR $\left(75 \mathrm{MHz}, \mathrm{CDCl}_{3}\right)$ $\delta$ (ppm); 118.9 (Ar), 122.6 (Ar), 129.9 (Py), 131.3 (Ar), 135.8 (Ar ( $_{\text {pso }}$ ), 140.8 (Ar-Br). MS (MALDI-TOF) m/z: 930.0 Anal. Calcd for.: $\mathrm{C}_{44} \mathrm{H}_{26} \mathrm{Br}_{4} \mathrm{~N}_{4}, \mathrm{C}$ 56.81, H 2.82, $\mathrm{Br} 34.36, \mathrm{~N} 6.02 \%$. Found: C 56.81, H 2.84, N 6.02\%.

5,10,15,20 ((tetra-(3,5-dibromophenyl) porphyrin $4.1 .48 \mathrm{~g}(1.20 \mathrm{mmol})$, yield $30 \%$. UV-Vis $\mathrm{CH}_{2} \mathrm{Cl}_{2}$ (nm); 402. 420, 450, 515, 552, 600, 653. FTIR $\mathrm{KBr}\left(\mathrm{cm}^{-1}\right) ; 2678,1578,1543$, 1478, 1421, 1400, 1364, 1340, 1279, 1248, 1154 , 1102, 1079 1055, 975, 898, 855, 797, 730, 708, 677, 640, 579, 536, 509. ${ }^{1} \mathrm{H}$ NMR (300 MHz, $\left.\mathrm{CDCl}_{3}\right) \delta$ (ppm): -3.02 (br, 2H, NH). 8.13 $(\mathrm{t}, 4 \mathrm{H}, J=1.8 \mathrm{~Hz}, \mathrm{Ar}), 8.29$ (d, 8H, $J=1.8 \mathrm{~Hz}, \mathrm{Ar}), 8.87$ (s, 8H, Py). ${ }^{13} \mathrm{C} \mathrm{NMR}\left(75 \mathrm{MHz}, \mathrm{CDCl}_{3}\right)$ 
$\delta(\mathrm{ppm}): 107.0$ (Ar), 121.5 (Ar), 130.9 (Py), 131.0 (Ar), 133.9 (Ar (ipso $_{\text {) }} 135.9$ (Aripso), 144.9 (Ar-Br) MS (MALDI-TOF) m/z: 1245. Anal. Calcd for.: $\mathrm{C}_{44} \mathrm{H}_{22} \mathrm{Br}_{8} \mathrm{~N}_{4}, \mathrm{C} 42.42, \mathrm{H} \mathrm{1.78,} \mathrm{Br}$ 51.31, N $4.50 \%$. Found: C 42.42, H 1.76, N $4.52 \%$.

\subsection{Synthesis of porphyrins 7-10.}

A mixture of (1.0 mol) of palladium acetate, boronic acid 5 or 6 (1.0 mol), KOH (1.0 $\mathrm{mol})$ in $25 \mathrm{~mL}$ of DMF, was added to the compound 3 or $4(1.0 \mathrm{~mol})$. The mixture was stirred at $70{ }^{\circ} \mathrm{C}$ for four hours. Then, the mixture was cooled at room temperature, and the solvent was evaporated under reduced pressure. The mixture was purified in a column chromatographic (silica gel 70-230 mesh) in $\mathrm{CH}_{2} \mathrm{Cl}_{2}$ mixture 90:10.

Porphyrin 7. Purple solid. Yield $188 \mathrm{mg}(0.20 \mathrm{mmol}) 30 \%$. UV-Vis $\mathrm{CHCl}_{3}(\mathrm{~nm}) ; 680$, 620, 455, 430, 260. IR KBr (cm $\left.{ }^{-1}\right)$; 3313, 3050, 3019, 2919, 2848, 2706, 2536, 1722, 1592, 1556, 1468, 1440, 1390, 1346, 1249, 1215, 1178, 1153, 1092, 1067, 1009, 984, 962, 875, 843, 794, 792, 698, 553, 519, 449. ${ }^{1} \mathrm{H}$ NMR (300 MHz, $\left.\mathrm{CDCl}_{3}\right) \delta$ (ppm): -2.98 (br, 2H, NH), 7.40 (t, $4 \mathrm{H}, J=7.8 \mathrm{~Hz}, \mathrm{Ar}) .7 .52$ (t, 8H, J=7.8 Hz, Ar), 7.87 (d, 8H, J=6.9 Hz, Ar), 7.95 (d, 8H, J= $7.8 \mathrm{~Hz}, \mathrm{Ar}), 8.25$ (d, 8H, J=8.1 Hz, Ar), $8.91(\mathrm{~s}, 8 \mathrm{H}, \mathrm{Py}),{ }^{13} \mathrm{C} \mathrm{NMR}\left(75 \mathrm{MHz}, \mathrm{CDCl}_{3}+\mathrm{CD}_{3} \mathrm{OD}\right)$ $\delta$ (ppm): 127.6 (Ar), 127.9 (Py), 127.6 (Ar), 127.9 (Py), 128.6 (Ar), 129.3 (Ar), 129.9 (Ar),

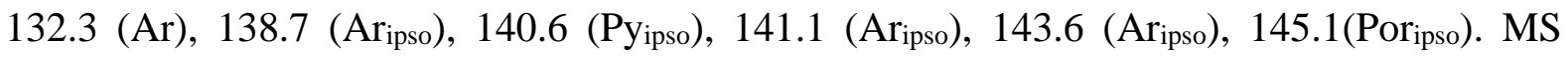
(MALDI-TOF) m/z: 919.4. Anal. Elem. calc. for: $\mathrm{C}_{68} \mathrm{H}_{46} \mathrm{~N}_{4}$. C 88.86, H 5.01, N 6.09 \%. Found: C 88.86, H 5.03, N $6.10 \%$.

Porphyrin 8. Purple solid. Yield $309 \mathrm{mg}(0.31 \mathrm{mmol}) 50 \%$. UV-Vis $\mathrm{CHCl}_{3}(\mathrm{~nm}) ; 650$, 590, 550, 512, 418, 400, 254. IR KBr ( $\left.\mathrm{cm}^{-1}\right)$; 3313, 3053, 3020, 2916, 2847, 2704, 2609, 2364, 2121, 1949, 1884, 1811, 1735, 1594, 1555, 1468, 1439, 1398, 1347, 1248, 1215, 1180, 1152 , 1072, 1030. ${ }^{1} \mathrm{H}$ NMR (300 MHz, $\left.\mathrm{CDCl}_{3}, \mathrm{CD}_{3} \mathrm{OD}\right) \delta(\mathrm{ppm}):-3.02$ (br, 2H, NH), 7.07 (d, 8H, $J=6.9 \mathrm{~Hz}, \mathrm{Ar}), 7.81$ (d, 8H, $J=6.9 \mathrm{~Hz}, \mathrm{Ar}), 7.97$ (d, 4H, $J=8.4 \mathrm{~Hz}, \mathrm{Ar}), 8.28$ (d, 8H, $J=5.1 \mathrm{~Hz}$, $\mathrm{Ar}$ ), 8.97 (s, 8H, py), ${ }^{13} \mathrm{C} \mathrm{NMR}\left(75 \mathrm{MHz}, \mathrm{CDCl}_{3}, \mathrm{CD}_{3} \mathrm{OD}\right) \delta$ (ppm): 119.7 (Ar), 123.9 (Ar),

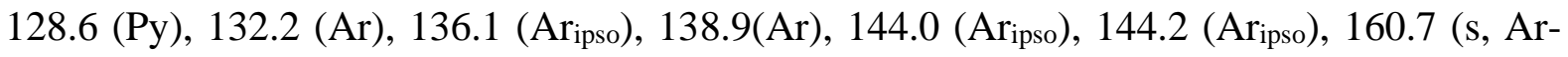
$\mathrm{OH}$ ), MS (MALDI-TOF) m/z: 983.7. Anal. Elem. calc. for: $\mathrm{C}_{68} \mathrm{H}_{46} \mathrm{~N}_{4} \mathrm{O}_{4} \cdot \mathrm{C}_{68} \mathrm{H}_{46} \mathrm{~N}_{4} \mathrm{O}_{4} . \mathrm{C} 83.08$, H 4.72, N 5.70. Found: C 83.08, H 4.70, N 5.71.

Porphyrin 9. Purple solid. Yield $176 \mathrm{mg}(0.14 \mathrm{mmol}) 30 \%$. UV-Vis $\mathrm{CHCl}_{3}(\mathrm{~nm}): 660$, 602, 450, 427, 350, 270. IR KBr ( $\left.\mathrm{cm}^{-1}\right): 3313,3031,2918,2849,1691,1590,1494,1472,1411$, 1361, 1317, 1265, 1241, 1178, 1153, 1074, 1029, 998, 973, 903, 881, 797, 755, 734, 693, 639, ${ }^{1} \mathrm{H}$ NMR $\left(300 \mathrm{MHz}, \mathrm{CDCl}_{3}\right) \delta(\mathrm{ppm}):-2.63(\mathrm{br}, 2 \mathrm{H}, \mathrm{NH}), 7.40(\mathrm{t}, 8 \mathrm{H}, \mathrm{J}=7.2 \mathrm{~Hz} \mathrm{~Hz}, \mathrm{Ar}), 7.51$ (t, 16H, J=7.5 Hz, Ar), 7.93 (d, 16H, J=7.5 Hz, Ar), 8.26 (s, 4H, Ar), 8.50 (s, 8H, Ar), 9.06 (s, 8H, Py). ${ }^{13} \mathrm{C}$ NMR (75 MHz, $\left.\mathrm{CDCl}_{3}\right) \delta(\mathrm{ppm}): 100.0$ (Ar), 121.1(Ar), 125.4 (Ar), 127.7 (Ar), 129.0 (Py), 132.7 (Ar), 138.5 (Ar), 140.1 (Ar), 140.9 (Ar ipso $_{\text {) }}, 143.1$ (Ar ( $_{\text {ipso }}$ ), 163.2 (Ar Apso $_{\text {ip. }}$ MS (MALDI-TOF) m/z: 1222.3. Anal. Elem. calc. for: $\mathrm{C}_{92} \mathrm{H}_{62} \mathrm{~N}_{4}$. C 90.31, H 5.11, N $4.58 \%$. Found: C 90.33, H 5.10, N $4.59 \%$.

Porphyrin 10. Purple solid. Yield $174 \mathrm{mg}(0.13 \mathrm{mmol}) 30 \%$. UV-Vis $\mathrm{CHCl}_{3}(\mathrm{~nm}): 650$, 590, 550, 515, 420, 400, 270. IR KBr $\left(\mathrm{cm}^{-1}\right): 3286,3030,2921,2852,1662,1588,1560,1511$, 1448, 1409, 1366, 1263, 1224, 1172, 1106, 1014, 976, 906, 817, 726, 700, 606, 559, 524, 493. ${ }^{1} \mathrm{H}$ NMR $\left(75 \mathrm{MHz}, \mathrm{CDCl} 3, \mathrm{CD}_{3} \mathrm{OD}\right) \delta(\mathrm{ppm}):-2.58(\mathrm{~s}, 2 \mathrm{H}, \mathrm{NH}), 6.86(\mathrm{~d}, 16 \mathrm{H}, J=8.7 \mathrm{~Hz}, \mathrm{Ar})$, 7.76 (d, 16H, J= 8.7 Hz, Ar), 8.17 (s, 4H, Ar), 8.42 (d, 8H, J=17.4 Hz, Ar), 9.03 (s, 8H, Py), ${ }^{13} \mathrm{C}$ NMR (75 MHz, $\left.\mathrm{CDCl}_{3}, \mathrm{CD}_{3} \mathrm{OD}\right) \delta(\mathrm{ppm}): 100.0$ (Ar), 115.1 (Ar), 128.3 (Py), 115.6 (Ar), 131.1 (Ar), 131.6 (Ar), 131.9 (Ar ipso $_{\text {ip }}, 139.9\left(\mathrm{Ar}_{\mathrm{ipso}}\right), 147.9$ (Ar $\left.\mathrm{Apso}_{\mathrm{ipo}}\right), 157.6$ (Ar-OH), MS 
(MALDI-TOF) m/z: 1350.1 Anal. Elem. calc. for: $\mathrm{C}_{92} \mathrm{H}_{62} \mathrm{~N}_{4} \mathrm{O}_{8} . \mathrm{C}$ 81.76, H 4.62, N $4.15 \%$. Found: C 81.74, H 4.60, N $4.17 \%$.

\section{Results and Discussion}

\subsection{Synthesis of porphyrins.}

Porphyrins 3 and 4 were obtained by the reaction of p-bromobenzaldehyde $\mathbf{1}$ or 3,5 dibromobenzaldehyde 2 with pyrrole, under classical conditions in boiling propionic acid (Scheme 1). The resulting tetrakis(p-bromophenyl) porphyrin 3 and octabromophenyl porphyrin 4 were crystallized directly from the cooled reaction mixture. The crystals were washed with EtOH in order to remove traces of acetic acid. The overall yield obtained was $50 \%$.

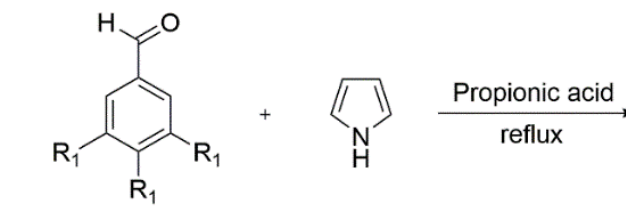

$$
\begin{aligned}
& 1\left(R_{1}=H ; R_{2}=B r ; R_{3}=H\right) \\
& 2\left(R_{1}=B r ; R_{2}=H ; R_{3}=B r\right)
\end{aligned}
$$

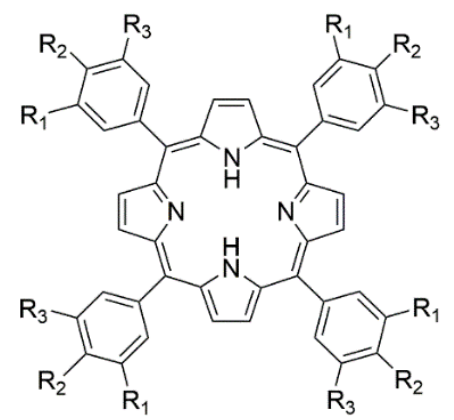

$$
\begin{aligned}
& 3\left(R_{1}=H ; R_{2}=B r ; R_{3}=H\right) \\
& 4\left(R_{1}=B r ; R_{2}=H ; R_{3}=B r\right)
\end{aligned}
$$

Scheme 1. Synthesis of tetrakis(p-bromophenyl) 3 and octabromophenyl 4 porphyrins.

The porphyrin 3 was characterized by ${ }^{1} \mathrm{H}$ NMR spectroscopy, and the following signals were observed, one singlet at $\delta_{\mathrm{H}}-2.77$, one broad signal assigned to the $\mathrm{NH}$ protons at $\delta_{\mathrm{H}} 8.06$ and $\delta_{\mathrm{H}} 7.90$ two doublets due to the aromatic protons and one singlet at 8.84 due to the $\mathrm{CH}$ beta pyrrolic protons. For compound $\mathbf{3}$, the structure was confirmed by X-ray diffraction analysis. The general view of molecule $\mathbf{3}$ and the packing of the molecules in the crystals are represented in Figure 1.
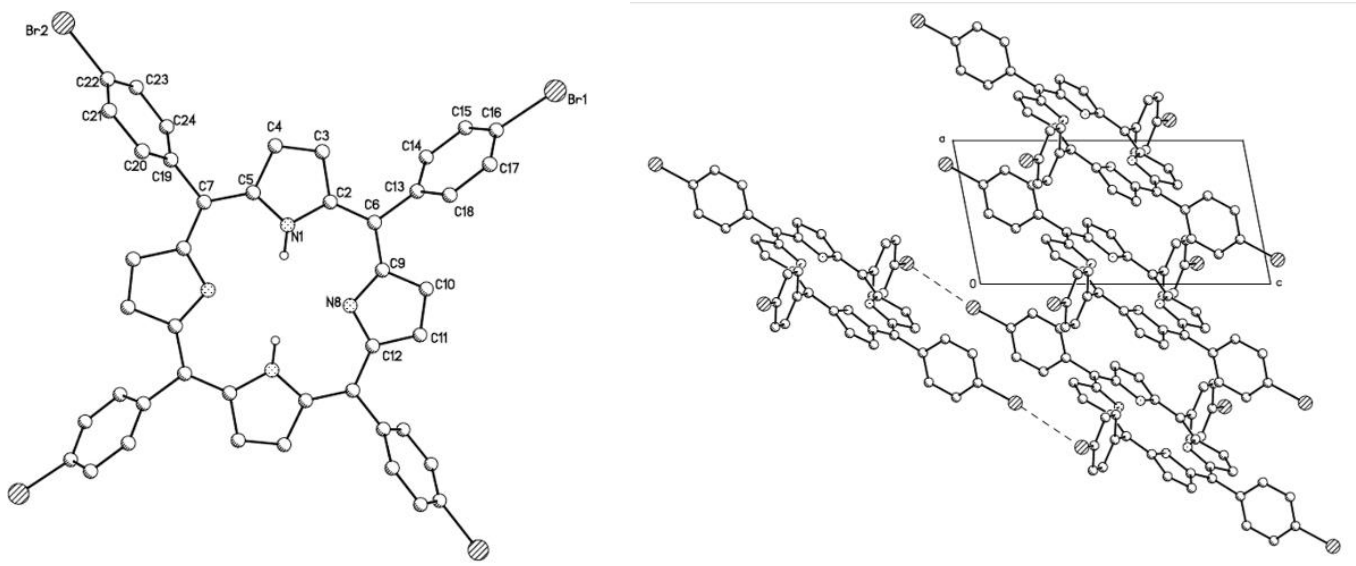

Figure 1. Crystal structure and crystal packing of compound 3. Selected bond lengths $(\AA)$ : $C(16)$ $\mathrm{Br}(1)=1.920, \mathrm{C}(16)-\mathrm{C}(17)=1.371, \mathrm{C}(15)-\mathrm{C}(16)=1.361, \mathrm{C}(14)-\mathrm{C}(15)=1.386, \mathrm{C}(13)-\mathrm{C}(14)=1.388, \mathrm{C}(6)-$ $\mathrm{C}(13)=1.484$. Selected bond angles $\left(^{\circ}\right)$ : $\mathrm{C}(5)-\mathrm{N}(1)-\mathrm{C}(2)=108.1, \mathrm{~N}(1)-\mathrm{C}(2)-\mathrm{C}(6)=126.8, \mathrm{~N}(1)-\mathrm{C}(2)-\mathrm{C}(3)=108.3$, $\mathrm{C}(6)-\mathrm{C}(2)-\mathrm{C}(3)=124.9, \mathrm{C}(4)-\mathrm{C}(3)-\mathrm{C}(2)=107.6, \mathrm{C}(3)-\mathrm{C}(4)-\mathrm{C}(5)=107.6, \mathrm{~N}(1)-\mathrm{C}(5)-\mathrm{C}(7)=126.7, \mathrm{~N}(1)-\mathrm{C}(5)-$ $\mathrm{C}(4)=108.4$. 
After characterizing the porphyrins $\mathbf{3}$ and 4, we used the Suzuki-Miyaura reaction to obtain the porphyrin derivatives 7-10. The porphyrins 3 and $\mathbf{4}$ were reacted with phenylboronic acid 5 or $p$-hidroxiphenyl boronic acid 6 in DMF and palladium acetate with $\mathrm{KOH}$. The mixture was stirred for $4 \mathrm{~h}$ at $70{ }^{\circ} \mathrm{C}$, obtaining the porphyrins 7-10 with good yields at 40 to $50 \%$ (Scheme 2).
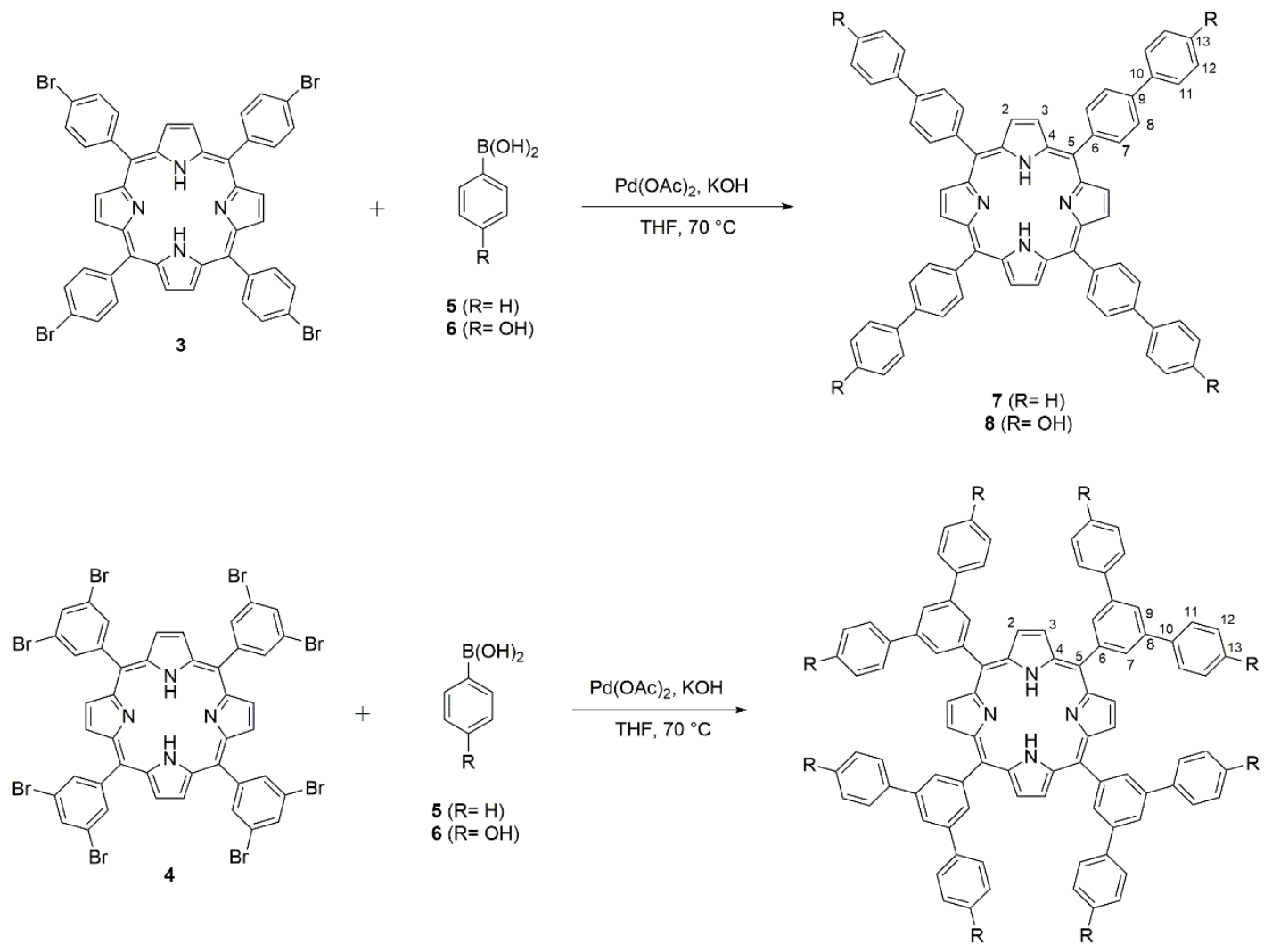

Scheme 2. Synthesis of porphyrins 7-10.

The porphyrins 7-10 were characterized by ${ }^{1} \mathrm{H}$ NMR, and in the spectrum, the characteristic porphyrin signals were observed. The signal at $\delta_{\mathrm{H}} 8.85-9.3$ due to the out protons at the pyrrole ring and doublets and triplets for the aromatic protons. In Figure 2, the ${ }^{1} \mathrm{H}$ NMR spectrum of the porphyrins $\mathbf{7 - 1 0}$ is shown.

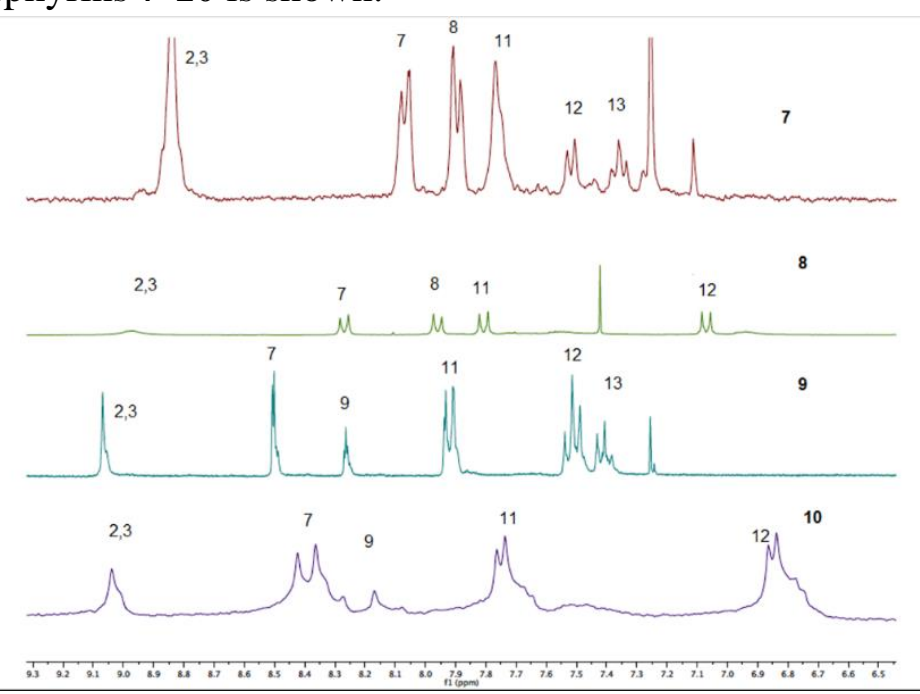

Figure 2. ${ }^{1} \mathrm{H}$ NMR spectra in the aromatic field of the porphyrins 7-10. 


\subsection{ESR studies.}

Porphyrins display the highly delocalized electrons of a conjugate system. Signals observed for the non-metallated porphyrins are basically due to two effects, the first is due to the interaction of unpaired $\pi$ electrons with the nuclear spin of the nitrogen atoms contained in the porphyrin ring $\mathrm{I}_{\mathrm{N}}=1$, and the second is due to the presence of a reversibly absorbed oxygen in the porphyrin ring. This effect has been observed in porphyrins and phthalocyanines [22,23]. Our experiments were made at room temperature and measured in the solid-state without using any spin trap, without illumination, and then illuminated at $400 \mathrm{~nm}$ with UV light. The ESR analysis of 7, 8, 9, and $\mathbf{1 0}$ in the solid-state produced a persistent signal as a single (Figure 3), in all cases with $g$ values around $2.0030 \pm 0.0011$ and very narrow signals of the order of $\Delta \mathrm{H}=$ $0.57 \mathrm{mT}$ wide, all these attributable to organic radicals. Hyperfine splitting was observed due to coupling with the nuclear spin of nitrogen $I_{N}=1$. Experimental results show no effect of the signal obtained with illumination. The signal was associated with the interaction between the porphyrins and oxygen [24], and the signal intensity depends on the amount of $\mathrm{O}_{2}$ produced $[25,26]$. The porphyrins 7 and $\mathbf{9}$ showed higher signal intensity and were able to stabilize better the superoxide anion than the porphyrins $\mathbf{8}$ and 10. This could be due to the presence of four and eight hydroxyl groups in the structure.

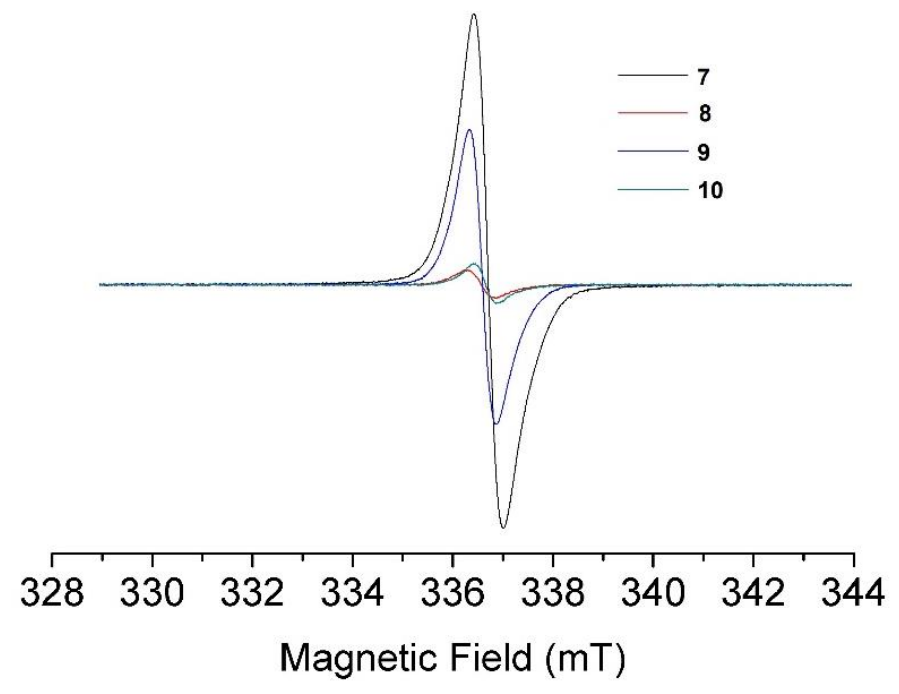

Figure 3. ESR spectra of the porphyrin derivatives 7-10.

\subsection{Optical properties.}

The high conjugation of the porphyrins 7-10 shows two intense absorptions Soret bands: Bx and by at 420 and at $458 \mathrm{~nm}$ and the Q bands between 528 and $685 \mathrm{~nm}$ (Figure 4). All the spectra are quite similar, but the maximum absorption spectrum of the porphyrins $\mathbf{8}$ and $\mathbf{1 0}$ with $\mathrm{OH}$ groups is bigger than the spectra of the porphyrins 7 and 9. These $\mathrm{Bx}$ and $\mathrm{By}$ bands are also slightly blue-shifted compared to $426 \mathrm{~nm}$ for the compound 7 to 422 for the compound 9, indicating the formation of aggregates and the excitonic transitions. This could be due to the presence of the four and eight $\mathrm{OH}$ groups in the porphyrin molecule and the formation of the intermolecular $\mathrm{O}---\mathrm{H}$ bonds. The increased conjugation along the $\mathrm{x}$-axis of the compounds 8-10 and a big peak absorbance were observed from the Qx transition at 668 $\mathrm{nm}$. This increase in absorption agrees with the increased oscillator strength of the Qx transition by introducing more phenyl units. 

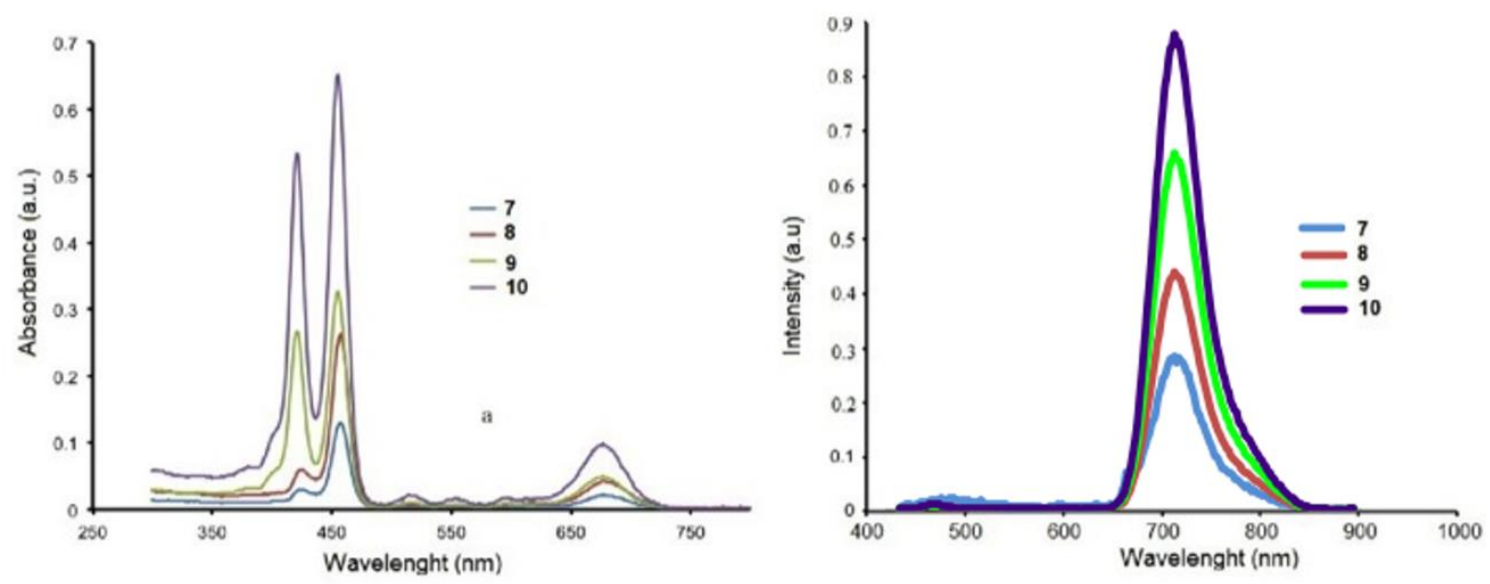

Figure 4. (a) Absorption and (b) emission spectra of the porphyrins 7-10 in $\mathrm{CH}_{2} \mathrm{Cl}_{2}$ at room temperature solution $1 \times 10^{-6} \mathrm{~mol} / \mathrm{L}$.

Excitation of diluted dichloromethane solutions of compounds 7-10 results in the characteristic porphyrin emission bands. The emission spectra were recorded at $24{ }^{\circ} \mathrm{C}$. Two bands at 654 and $710 \mathrm{~nm}$ were observed in the red region of compound 7. For compounds 710, the emission spectra showed one broad peak due to stabilizing the $S_{1}$ and $S_{2}$ states. No emission was observed in any case when the samples were excited in the phenyl absorption band. The lowest energy emission band increased in intensity for the porphyrin 10. The fluorescence quantum yields increase as the number of phenyl moieties in the molecule increase (Table 1).

Table 1. Summarized absorbance data $\left(\mathrm{CH}_{2} \mathrm{Cl}_{2}\right)$.

\begin{tabular}{c|c|c|c|c|c} 
Compound & $\boldsymbol{\lambda}_{\text {abs }}(\mathbf{n m})$ & $\lambda_{\text {emis }}(\mathbf{n m})$ & $\mathbf{E g}(\mathbf{e V})$ & Stok shift $(\mathbf{n m})$ & $\boldsymbol{\Phi}(\boldsymbol{\%})$ \\
\hline $\mathbf{7}$ & $426,465,528,562,627,684$ & 654,710 & 2.56 & 245 & 5.71 \\
\hline $\mathbf{8}$ & $422,458,524,552,685$ & 710 & 2.54 & 252 & 5.87 \\
\hline $\mathbf{9}$ & $422,456,524,559,600,683$ & 710 & 2.57 & 254 & 6.92 \\
\hline $\mathbf{1 0}$ & $420,454,520,559,600,682$ & 710 & 2.59 & 256 & 6.44
\end{tabular}

\section{Conclusions}

The application of the Suzuki-Miyaura approach outlined here allows us to synthesize porphyrins with multiphenyl components, obtaining molecules with two or three phenyl units in the meso position and high molecular weights. Since the mild and simple conditions to carry out the reactions allow a wide tolerance of functional groups, this approach could be applicable to obtain other higher structurally uniform and well-defined polyphenylporphyrin systems in good yields.

\section{Funding}

This research received no external funding.

\section{Acknowledgments}

This work was supported by DGAPA-UNAM (IN232220) grant, and FGA was supported by a postdoctoral fellowship from CONACyT No. 2020-000022-01NACV-00170. We would also like to thank Rios O. H., Velasco L., Huerta S. E., Patiño M. M. R., Peña Gonzalez M. A., García Rios E., Orta Pérez M. for technical assistance. 


\section{Conflicts of Interest}

The authors declare no conflict of interest.

\section{References}

1. Amiri, N.; Guergueb, M.; Al-Fakeh, M.S.; Bourguiba, M.; Nasri, H. A new cobalt(II) meso-porphyrin: synthesis, characterization, electric properties and application in the catalytic degradation of dyes. RSC Adv., 2020, 10, 44920-44932. https://doi.org/10.1039/D0RA08786F.

2. Molnar, E.; Gál, E.; Gaina, L.; Cristea, C.; Silaghi-Dumitrescu, L. Ethyne Functionalized MesoPhenothiazinyl-PhenylPorphyrins: Synthesis and Optical Properties of Free Base Versus Protonated Species. Molecules, 2020, 25, 4546. https://doi.org/10.3390/molecules25194546.

3. Arcidiacono, A.; Zhou, Y.; Zhang, W.; Ellison, J.O.; Ayad, S.; Knorr, E.S.; Peters, A.N.; Zheng, L.; Yang, W.; Saavedra, S.S.; Hanson, K. Examining the influence of bilayer structure on energy transfer and molecular photon upconversion in metal ion linked multilayers. J. Phys. Chem. C. Nanomater Interfaces, 2020, 124, 23597-23610. https://doi.org/10.1021/acs.jpcc.0c08715.

4. Qi, Z.L.; Cheng, Y.H.; Xu, Z.; Chen, M.L. Recent Advances in Porphyrin-Based Materials for Metal Ions Detection. Int. J. Mol. Sci., 2020, 21, 5839. https://doi.org/10.3390/ijms21165839.

5. Otieno, S.; Lanterna, A.E.; Mack, J.; Derese, S.; Amuhaya, E.K.; Nyokong, T.; Scaiano, J.C. Solar Driven Photocatalytic Activity of Porphyrin Sensitized TiO2: Experimental and Computational Studies. Molecules, 2021, 26, 3131. https://doi.org/10.3390/molecules26113131.

6. Al Mogren, M.M.; Ahmed, N.M.; Hasanein, A.A. Molecular modeling and photovoltaic applications of porphyrin-based dyes: A review. J. Saudi Chem. Soc., 2020, 24, 303-320. https://doi.org/10.1016/j.jscs.2020.01.005.

7. Luchs, T.; Zieleniewska, A.; Kunzmann, A.; Schol, P.R.; Guldi, D.M.; Hirsch, A. Non-Covalent Postfunctionalization of Dye Layers on $\mathrm{TiO}_{2}$ - A Tool for Enhancing Injection in Dye-Sensitized Solar Cells. Chem. Eur. J., 2021, 27, 5041-5050. https://doi.org/10.1002/chem.202004928.

8. Chiang, Y.J.; Hsiao, Y.H.; Chen, Y.H.; Hung, C.M.; Chen, H.C.; Yeh, C.Y. All-Porphyrin Photovoltaics with Power Conversion Efficiency of 7.2\%. ACS Energy Lett. 2020, 5, 2641-2650. https://doi.org/10.1021/acsenergylett.0c01128.

9. Nisa, K.; Khatri, V.; Kumar, S.; Arora, S.; Ahmad, S.; Dandia, A.; Thimural, M.; Kashyap, H.K.; Chauhan, S.M.S. Synthesis and Redox Properties of Superbenzene Porphyrin Conjugates. Inorg. Chem., 2020, 59, 16168-16177. https://doi.org/10.1021/acs.inorgchem.0c01682.

10. Ferrero, S.; Barbero, H.; Miguel, D.; García-Rodríguez, R.; Álvarez, C.M. Porphyrin-based systems containing polyaromatic fragments: decoupling the synergistic effects in aromatic-porphyrin-fullerene systems. RSC Adv., 2020, 10, 36164-36173. https://doi.org/10.1039/D0RA07407A.

11. Ueda, M.; Kimura, M.; Miyagawa, S.; Takada, H.; Naito, M.; Tokunaga, Y. A Five-layer $\pi$-Aromatic Structure Formed through Self-assembly of a Porphyrin Trimer and Two Aromatic Guests. Chem Asian J., 2020, 15, 2212-2217. https://doi.org/10.1002/asia.202000452.

12. Specht, A.; Bolze, F.; Donato, L.; Herbivo, C.; Charon, S.; Warther, D.; Gug, S.; Nicoud, J.F.; Goeldner, M. The donor-acceptor biphenyl platform: A versatile chromophore for the engineering of highly efficient twophoton sensitive photoremovable protecting groups. Photochem. Photobiol. Sci., 2012, 11, 578-586. https://doi.org/10.1039/C2PP05360H.

13. Shi, K.; Song, N.; Zou, Y.; Zhu, S.; Tan, H.; Tian, Y.; Zhang, B.; Yao, H.; Guan, S. Porphyrin-based porous polyimides: Synthesis, porous structure, carbon dioxide adsorption. Polymer, 2019, 169, 160-169. https://doi.org/10.1016/j.polymer.2019.02.062.

14. Liu, C.; Liu, K.; Wang, C.; Liu, H.; Wang, H.; Su, H.; Li, X.; Chen, B.; Jiang, J. Elucidating heterogeneous photocatalytic superiority of microporous porphyrin organic cage. Nat. Commun., 2020, 11, 1047. https://doi.org/10.1038/s41467-020-14831-x.

15. Oh, I.; Lee, H.; Kim. T.W.; Kim, C.W.; Jun, S.; Kim, C.; Choi, E.H.; Rhee, Y.M.; Kim, J.; Jang, W.D.; Ihee, H. Enhancement of Energy Transfer Efficiency with Structural Control of Multichromophore LightHarvesting Assembly. Adv. Sci., 2020, 7, 2001623. https://doi.org/10.1002/advs.202001623.

16. Minotto, A.; Bulut, I.; Rapidis, A.G.; Carnicella, G.; Patrini, M.; Lunedei, E.; Anderson, H.L.; Cacialli, F. Towards efficient near-infrared fluorescent organic light-emitting diodes. Light Sci. Appl., 2021, 10, 1-10. https://doi.org/10.1038/s41377-020-00456-8. 
17. Gou, F.; Jiang, X.; Fang, R.; Jing, H.; Zhu, Z. Strategy to Improve Photovoltaic Performance of DSSC Sensitized by Zinc Prophyrin Using Salicylic Acid as a Tridentate Anchoring Group. ACS Appl. Mater. Interfaces, 2014, 6, 6697-6703. https://doi.org/10.1021/am500391w.

18. Xu, F.; Testoff, T.T.; Wang, L.; Zhou, X. Cause, Regulation and Utilization of Dye Aggregation in DyeSensitized Solar Cells. Molecules, 2020, 25, 4478. https://doi.org/10.3390/molecules25194478.

19. Chen, J.; Zhu, Y.; Kaskel, S. Porphyrin-Based Metal-Organic Frameworks for Biomedical Applications. Angew. Chem. Int. Ed., 2021, 60, 5010-5035. https://doi.org/10.1002/anie.201909880.

20. Feng, L.; Wang, K.Y.; Joseph, E.; Zhou, H.C. Catalytic Porphyrin Framework Compounds. Trends Chem., 2020, 2, 555-568. https://doi.org/10.1016/j.trechm.2020.01.003.

21. Mone, M.; Tang, S.; Murto, P.; Abdulahi, B.A.; Larsen, C.; Wang, J.; Mammo, W.; Edman, L.; Wang, E. Star-Shaped Diketopyrrolopyrrole-Zinc Porphyrin that Delivers $900 \mathrm{~nm}$ Emission in Light-Emitting Electrochemical Cells. Chem. Mater., 2019, 31, 9721-9728. https://doi.org/10.1021/acs.chemmater.9b03312.

22. Garfias-Gonzalez, K.I.; Organista-Mateos, U.; Borja-Miranda, A.; Gomez-Vidales, V.; Hernandez-Ortega, S.; Cortez-Maya, S.; Martínez-García, M. High Fluorescent Porphyrin-PAMAM-Fluorene Dendrimers. Molecules, 2015, 20, 8548-8559. https://doi.org/10.3390/molecules20058548.

23. Gutiérrez-Meza, E.; Noria, R.; Granados, G.; Gómez-Vidales, V.; Zeferino-Ramírez, J.; Beltrán, H.I.; Peon, P. Photophysics of a Cis Axially Disubstituted Macrocycle: Rapid Intersystem Crossing in a Tin ${ }^{\text {IV }}$ Phthalocyanine with a Half-Domed Geometry. J. Phys. Chem. B, 2012, 116, 14107-14114. https://doi.org/10.1021/jp3078453.

24. Lin, Q.S.; Zhang, T.L.; Yuan, L.B. Study of ESR spectra and photochemical reaction of porphyrin derivatives. Chin. J. Appl. Chem., 1988, 5, 57-61.

25. Assour, J.M.; Harrison, S.E. On the Origin of Unpaired Electrons in Metal-Free Phthalocyanine. J. Phys. Chem., 1964, 68, 872-876. https://doi.org/10.1021/j100786a029.

26. Granados-Oliveros, G.; Paez-Mozo, E.A.; Martínez, F.O.; Turini, M.P.; Neves, F.S.; Barbosa, C.L.G. E.; Di Mauro; Ferreira da Costa, M; Tsutomu, AO. Visible light production of superoxide anion with MCarboxyphenylporphyrins $(\mathrm{M}=\mathrm{H}, \mathrm{Fe}, \mathrm{Co}, \mathrm{Ni}, \mathrm{Cu}$, and $\mathrm{Zn})$ free and anchored on $\mathrm{TiO}_{2}$ : EPR characterization. J. Mol. Cat. A: Chem., 2011, 339, 79-85. https://doi.org/10.1016/j.molcata.2011.02.015. 


\section{Supplementary materials}

1. Synthesis of porphyrins $\mathbf{3}, \mathbf{4}$.

A bottomed flask of $250 \mathrm{ml}$ equipped with a magnetic stirrer was added (21.74 mol) of p-bromobenzaldehyde, or 3,5-dibromonezaldehyde, $(21.74 \mathrm{~mol})$ of pyrrole and $25 \mathrm{ml}$ of propionic acid, the mixture was stirred and refluxed for 12 hours at $140^{\circ} \mathrm{C}$ under nitrogen atmosphere. After this time, the reaction mixture was cooled at room temperature, and $50 \mathrm{ml}$ of water was added. The crude reaction was filtered under a vacuum and washed with hot water. The solid was washed with methanol to obtain a purple solid.

\section{5,10,15,50-(tetra-p-bromophenyl) porphyrin 3.}

$1.02 \mathrm{~g}$ (1.63 mmol), yield $30 \%$ of the m.p >300 ${ }^{\circ} \mathrm{C}, \mathrm{UV}-\mathrm{Vis} \mathrm{CHCl}_{3}(\mathrm{~nm}) ; 290,370$, 420, 450, 616, 660. FTIR KBr $\left(\mathrm{cm}^{-1}\right)$; 3313, 1556, 1469, 1388, 1345, 1245, 1214, 1179, 1096, 1066, 1009, 985, 961, 873, 841, 749, 731, 709, 638, 553, 520, 449. ${ }^{1} \mathrm{H} \mathrm{NMR}\left(300 \mathrm{MHz}, \mathrm{CDCl}_{3}\right)$ $\delta$ (ppm): -2.85 (br, 2H, NH), 7.90 (d, 8H, J= 8.4 Hz, Ar), 8.06 (d, 8H, J=8.1 Hz, Ar), 8.84 (s, 8H, Pirrol). ${ }^{13} \mathrm{C}$ NMR (75 MHz, $\left.\mathrm{CDCl}_{3}\right) \delta$ (ppm); 118.9 (Ar), 122.6 (Ar), 129.9 (Py), 131.3 (Ar), 135.8 (Ar $\mathrm{Arss}_{\mathrm{ips}}$ ), 140.8 (Ar-Br). MS (MALDI-TOF) m/z: 930.0 Anal. Calcd for.: $\mathrm{C}_{44} \mathrm{H}_{26} \mathrm{Br}_{4} \mathrm{~N}_{4}, \mathrm{C} 56.81, \mathrm{H} 2.82, \mathrm{Br} 34.36, \mathrm{~N} 6.02 \%$. Found: C 56.81, H 2.84, N 6.02\%.

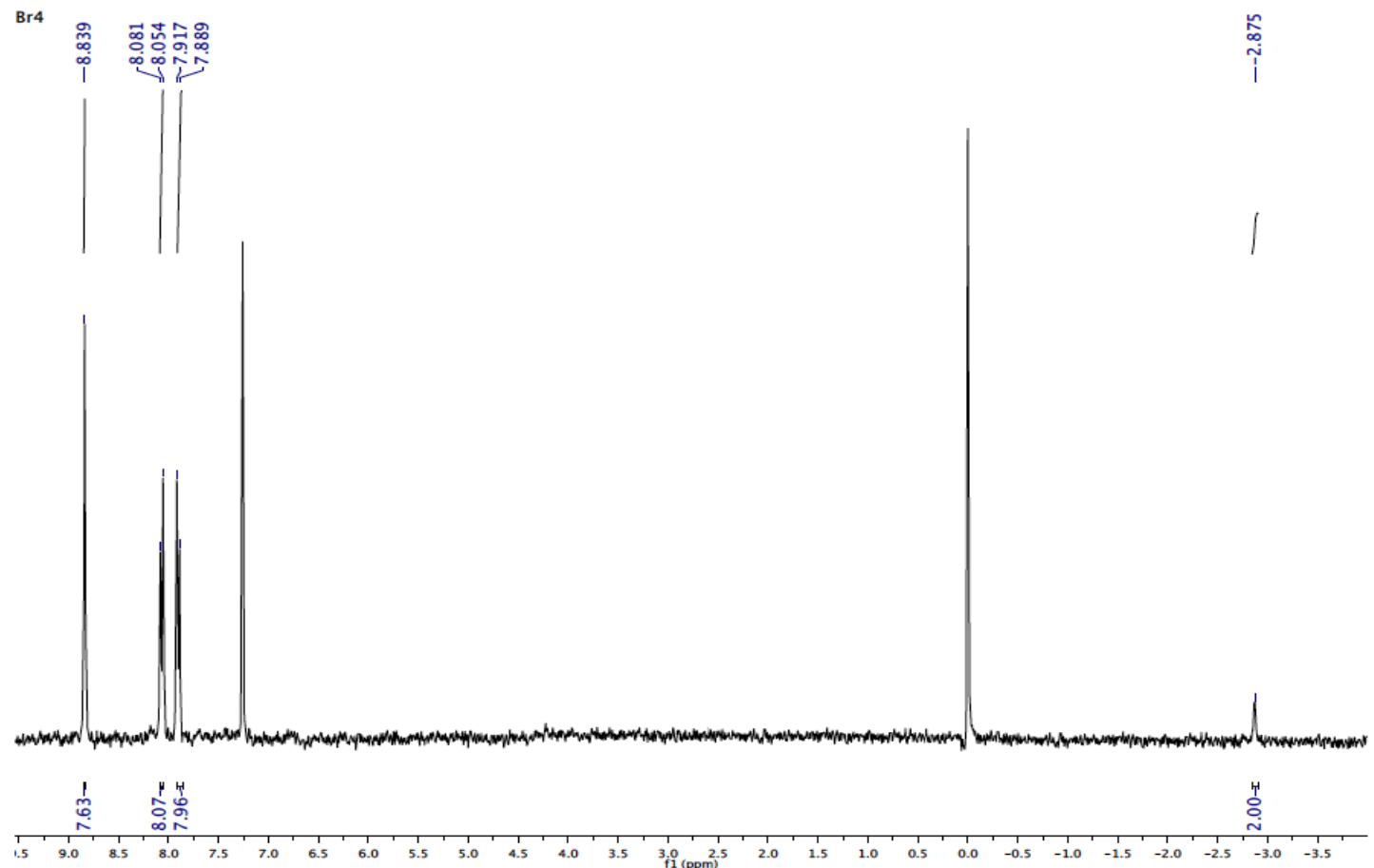

Figure 5. ${ }^{1} \mathrm{H}$ NMR for porphyrin 3.

\section{5,10,15,20 ((tetra-(3,5-dibromophenyl) porphyrin 4.}

$1.48 \mathrm{~g}$ (1.20 mmol), yield $30 \%$. UV-Vis $\mathrm{CH}_{2} \mathrm{Cl}_{2}(\mathrm{~nm})$; 402. 420, 450, 515, 552, 600, 653. FTIR KBr $\left(\mathrm{cm}^{-1}\right)$; 2678,1578, 1543, 1478, 1421, 1400, 1364, 1340, 1279, 1248, 1154 , 1102, 1079 1055, 975, 898, 855, 797, 730, 708, 677, 640, 579, 536, 509. ${ }^{1} \mathrm{H}$ NMR $(300 \mathrm{MHz}$, $\mathrm{CDCl}_{3}$ ) $\delta$ (ppm): -3.02 (an, 2H, NH). 8.13 (t, 4H, $\left.J=1.8 \mathrm{~Hz}, \mathrm{Ar}\right), 8.29$ (d, 8H, J=1.8 Hz, Ar), 8.87 (s, 8H, py). ${ }^{13} \mathrm{C} \mathrm{NMR}\left(75 \mathrm{MHz}, \mathrm{CDCl}_{3}\right) \delta$ (ppm): 107.0 (Ar), 121.5 (Ar), 130.9 (Py), 131.0 
(Ar), 133.9 (Ar (ipso) $_{135.9}$ (Aripso), 144.9 (Ar-Br) MS (MALDI-TOF) m/z: 1245. Anal. Calcd for.: $\mathrm{C}_{44} \mathrm{H}_{22} \mathrm{Br}_{8} \mathrm{~N}_{4}, \mathrm{C} 42.42, \mathrm{H}$ 1.78, Br 51.31, N 4.50 \%. Found: C 42.42, H 1.76, N $4.52 \%$.

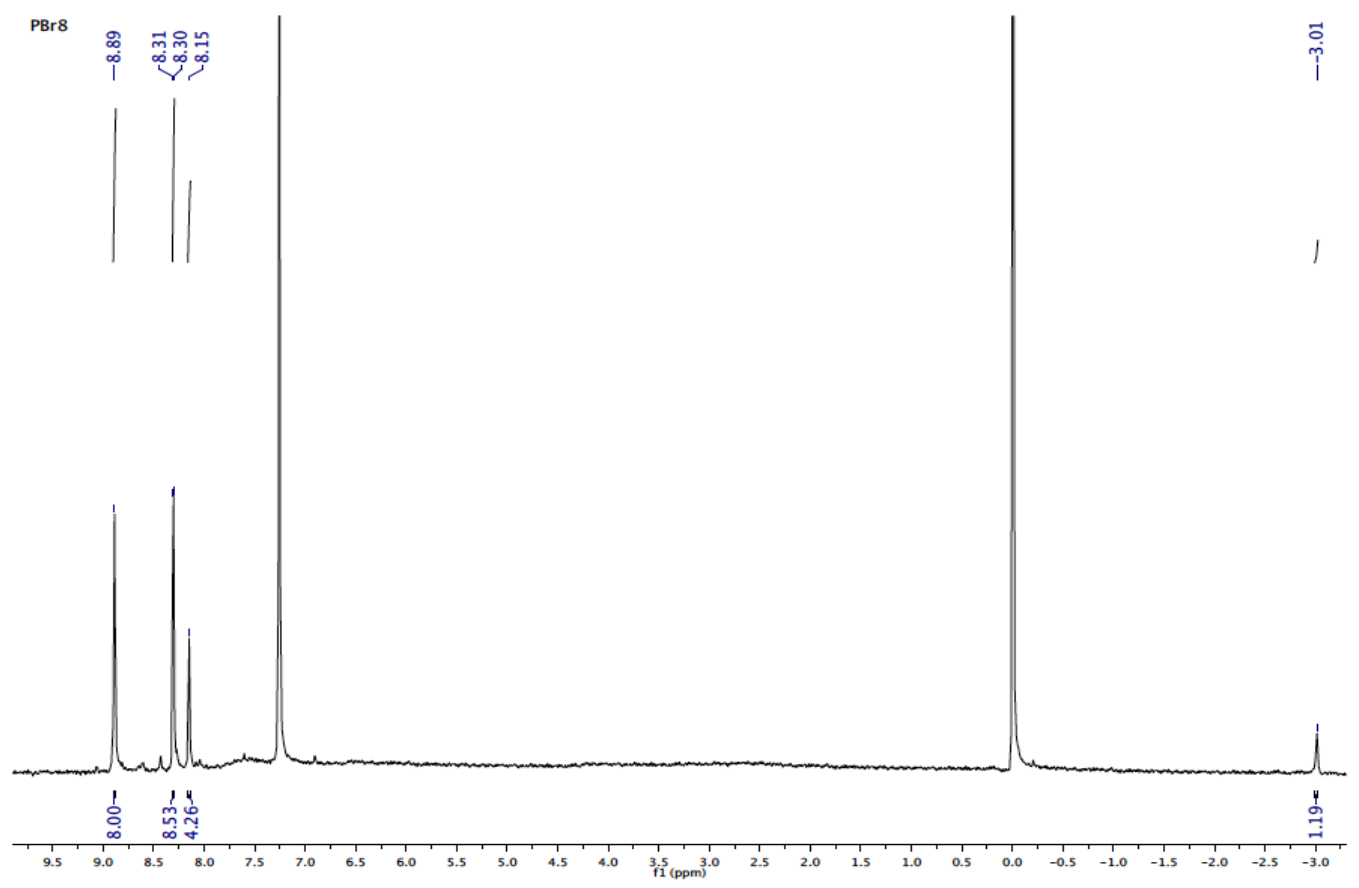

Figure 6. ${ }^{1} \mathrm{H}$ NMR for porphyrin 4.

\section{Synthesis of porphyrins 7-10.}

A mixture of (1 mol) of palladium acetate, boronic acid 5 or $6(1 \mathrm{~mol}), \mathrm{KOH}(1 \mathrm{~mol})$ in $25 \mathrm{ml}$ of DMF, was added to the compound 7-10 (1 mol). The mixture was stirred at $70{ }^{\circ} \mathrm{C}$ for four hours. The mixture was cooled at room temperature, and the solvent was evaporated under reduced pressure; the mixture was purified in a column chromatographic (silica gel 70-230 mesh) in $\mathrm{CH}_{2} \mathrm{Cl}_{2}$ mixture 90:10.

\section{Porphyrin 7.}

Purple solid. Yield $188 \mathrm{mg}(0.20 \mathrm{mmol}) 30 \%$. UV-Vis $\mathrm{CHCl}_{3}(\mathrm{~nm}) ; 680,620,455,430$, 260. IR KBr $\left(\mathrm{cm}^{-1}\right) ; 3313,3050,3019,2919,2848,2706,2536,1722,1592,1556,1468,1440$, 1390, 1346, 1249, 1215, 1178, 1153, 1092, 1067, 1009, 984, 962, 875, 843, 794, 792, 698, 553, 519, 449. ${ }^{1} \mathrm{H}$ NMR $\left(300 \mathrm{MHz}, \mathrm{CDCl}_{3}\right) \delta(\mathrm{ppm}):-2.98$ (br, $\left.2 \mathrm{H}, \mathrm{NH}\right), 7.40$ (t, 4H, J= $7.8 \mathrm{~Hz}$, Ar). 7.52 (t, $8 \mathrm{H}, J=7.8 \mathrm{~Hz}, \mathrm{Ar}), 7.87(\mathrm{~d}, 8 \mathrm{H}, J=6.9 \mathrm{~Hz}, \mathrm{Ar}), 7.95$ (d, 8H, $J=7.8 \mathrm{~Hz}, \mathrm{Ar}), 8.25$ (d, 8H, J=8.1 Hz, Ar), 8.91 (s, 8H, Py), $\left.{ }^{13} \mathrm{C} \mathrm{NMR} \mathrm{(75} \mathrm{MHz,} \mathrm{CDCl}_{3}+\mathrm{CD}_{3} \mathrm{OD}\right) \delta$ (ppm): 127.6 (Ar), 127.9 (Py), 127.6 (Ar), 127.9 (Py), 128.6 (Ar), 129.3 (Ar), 129.9 (Ar), 132.3 (Ar), 138.7 (Ar ipso $_{\text {) }}, 140.6$ (Pyipso), 141.1 (Ar ( $_{\text {ipso }}$ ), 143.6 (Aripso), 145.1(Por ( $_{\text {ipso }}$ ). MS (MALDI-TOF) m/z: 919.4. Anal. Elem. calc. for: $\mathrm{C}_{68} \mathrm{H}_{46} \mathrm{~N}_{4}$. C 88.86, H 5.01, N 6.09 \%. Found: C 88.86, H 5.03, N $6.10 \%$. 


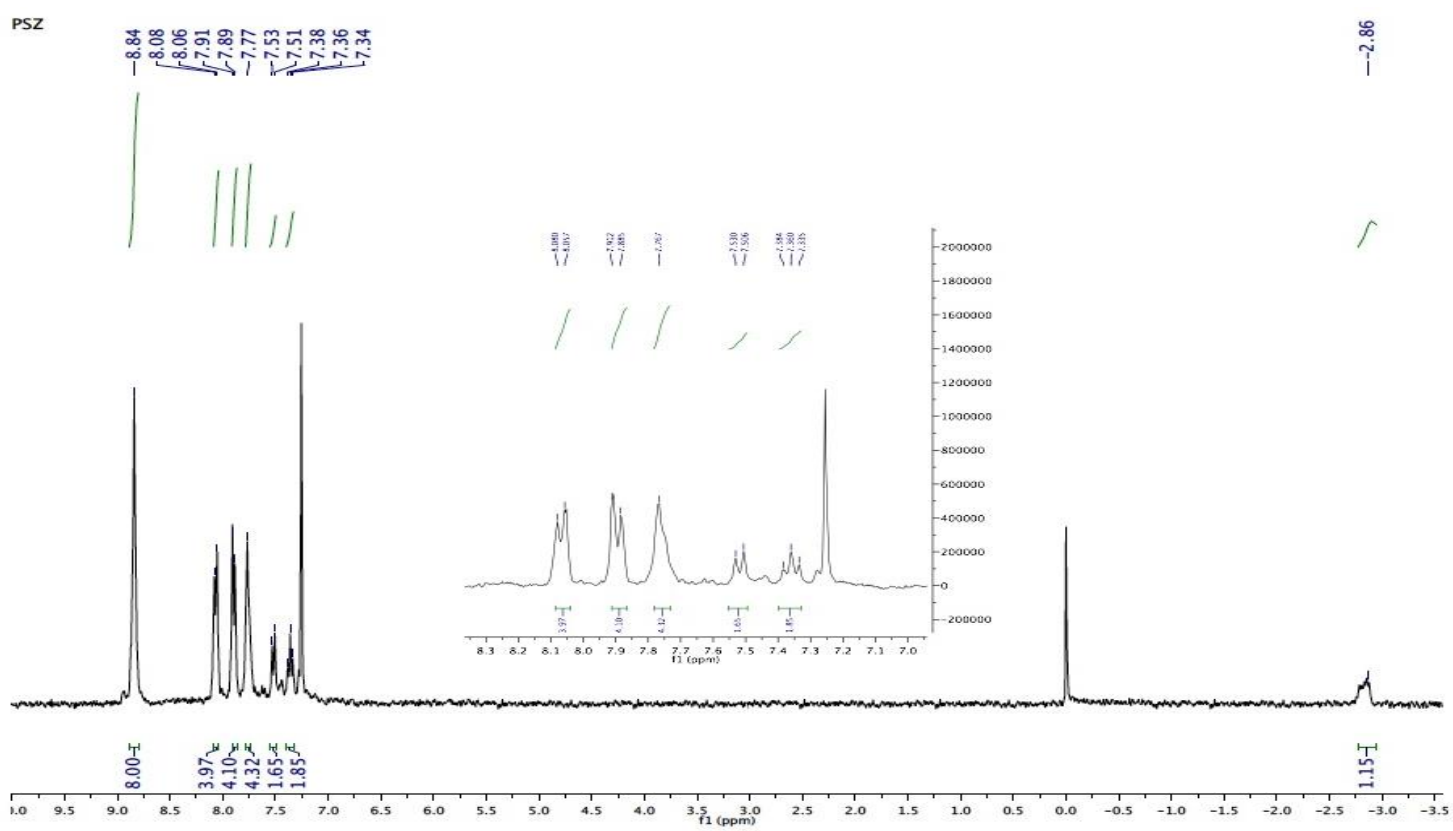

Figure 7. ${ }^{1} \mathrm{H}$ NMR for porphyrin 7.

\section{Porphyrin 8.}

Purple solid. Yield $309 \mathrm{mg}(0.31 \mathrm{mmol}) 50 \%$. UV-Vis $\mathrm{CHCl}_{3}(\mathrm{~nm})$; 650, 590, 550, 512 , 418, 400, 254. IR KBr (cm $\left.{ }^{-1}\right)$; 3313, 3053, 3020, 2916, 2847, 2704, 2609, 2364, 2121, 1949 , 1884, 1811, 1735, 1594, 1555, 1468, 1439, 1398, 1347, 1248, 1215, 1180, 1152, 1072, 1030, ${ }^{1} \mathrm{H}$ NMR (300 MHz, $\left.\mathrm{CDCl}_{3}, \mathrm{CD}_{3} \mathrm{OD}\right) \delta$ (ppm): -3.02 (br, 2H, NH), 7.07 (d, 8H, J=6.9 Hz, Ar), $7.81(\mathrm{~d}, 8 \mathrm{H}, J=6.9 \mathrm{~Hz}, \mathrm{Ar}), 7.97$ (d, 4H, J=8.4 Hz, Ar), 8.28 (d, 8H, J=5.1 Hz, Ar), 8.97 (s, $8 \mathrm{H}, \mathrm{py}),{ }^{13} \mathrm{C} \mathrm{NMR}\left(75 \mathrm{MHz}, \mathrm{CDCl}_{3}, \mathrm{CD}_{3} \mathrm{OD}\right) \delta$ (ppm): 119.7 (Ar), 123.9 (Ar), 128.6 (Py), 132.2 (Ar), 136.1 (Aripso), 138.9(Ar), 144.0 (Ar ( $\left._{\text {ipso }}\right), 144.2$ (Ar ipso $_{\text {) }}, 160.7$ (s, Ar-OH), MS (MALDI-TOF) m/z: 983.7. Anal. Elem. calc. for: $\mathrm{C}_{68} \mathrm{H}_{46} \mathrm{~N}_{4} \mathrm{O}_{4} \cdot \mathrm{C}_{68} \mathrm{H}_{46} \mathrm{~N}_{4} \mathrm{O}_{4}$. C 83.08, H 4.72, N 5.70. Found: C 83.08, H 4.70, N 5.71.

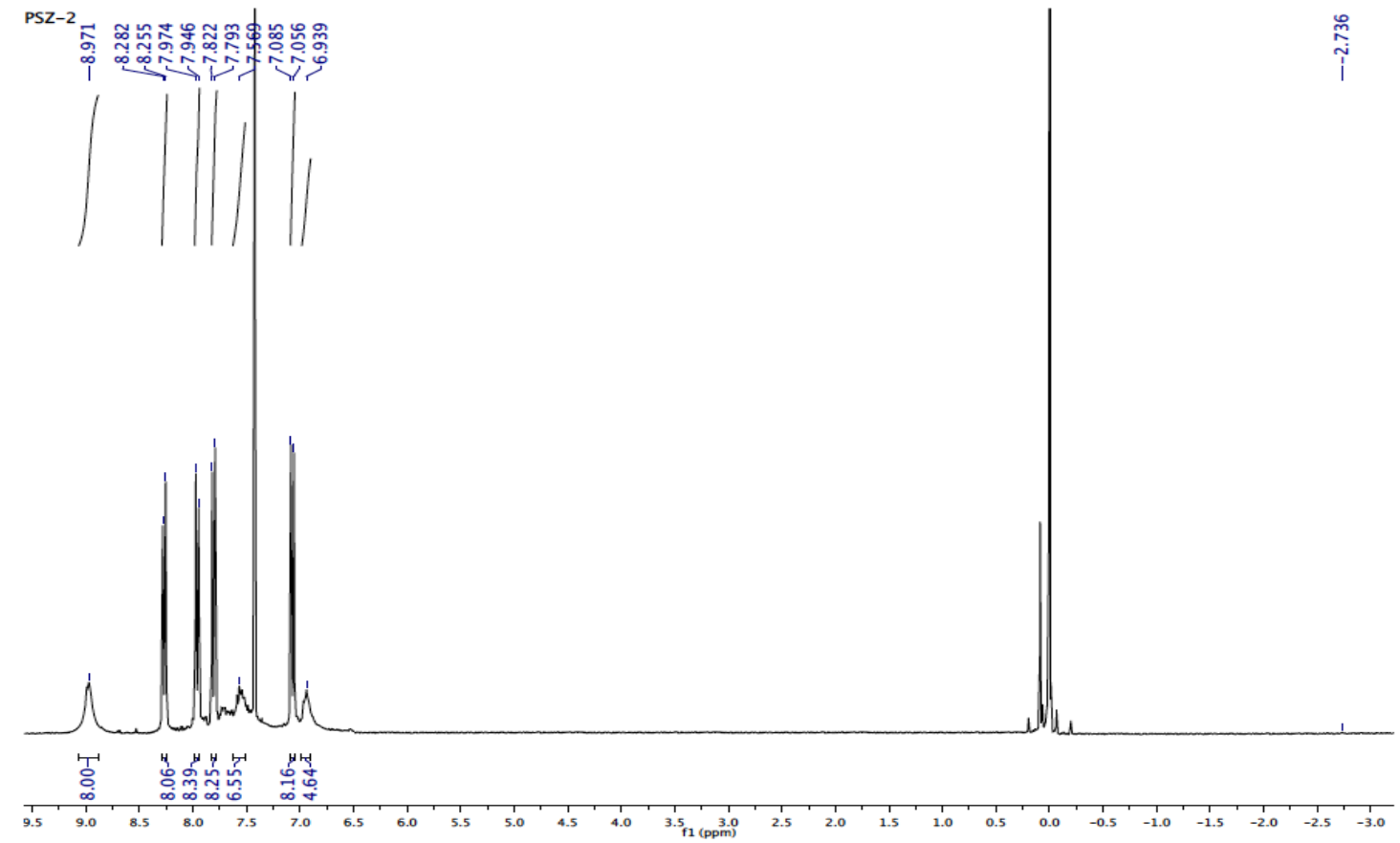

Figure 8. ${ }^{1} \mathrm{H}$ NMR for porphyrin 8. 


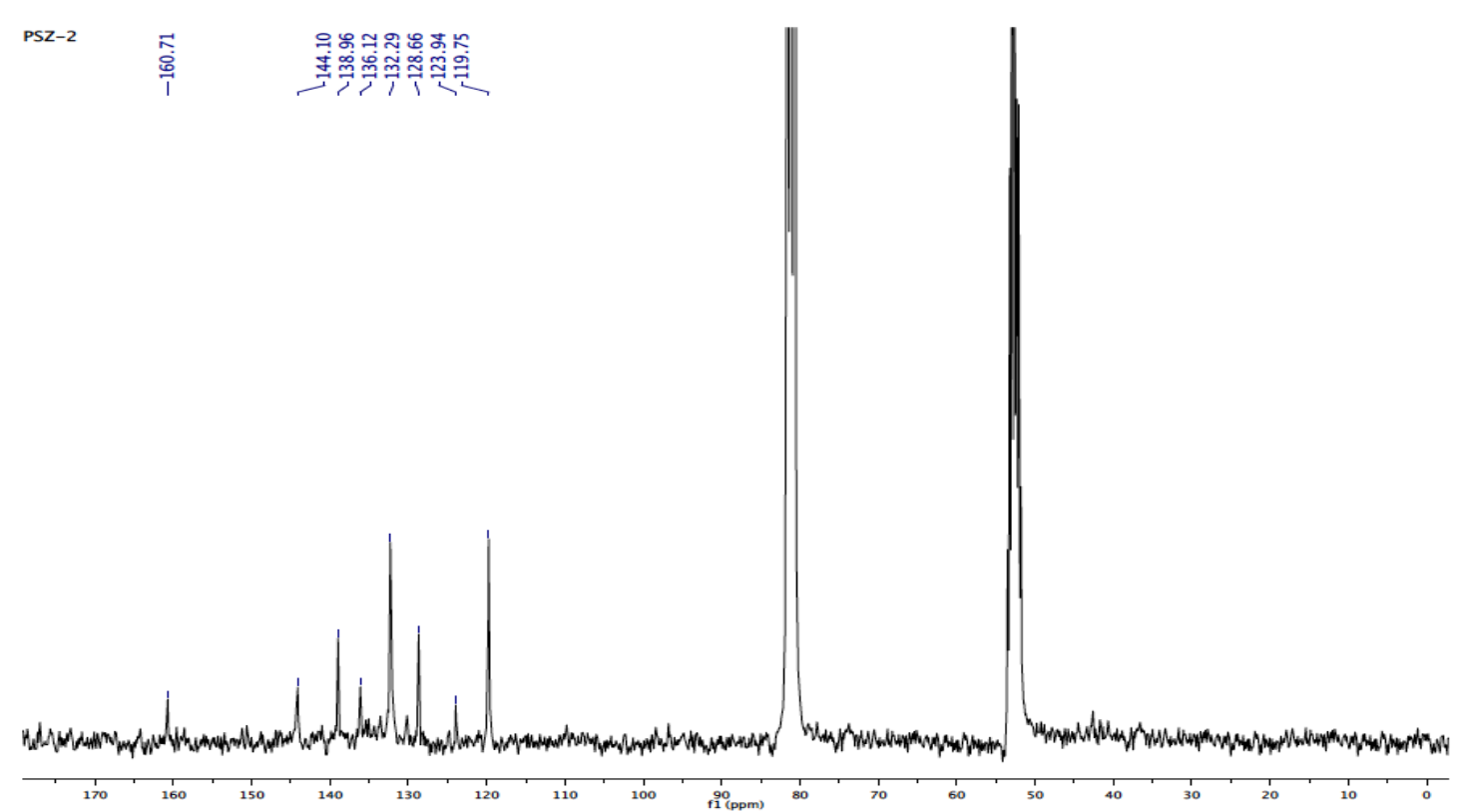

Figure $9 .{ }^{13} \mathrm{C}$ NMR for porphyrin 8 .

\section{Porphyrin 9.}

Purple solid. Yield $176 \mathrm{mg}$ (0.14 mmol) 30\%. UV-Vis $\mathrm{CHCl}_{3}$ (nm): 660, 602, 450, 427, 350, 270. IR KBr $\left(\mathrm{cm}^{-1}\right): 3313,3031,2918,2849,1691,1590,1494,1472,1411,1361,1317$, $1265,1241,1178,1153,1074,1029,998,973,903,881,797,755,734,693,639,{ }^{1} \mathrm{H}$ NMR $\left(300 \mathrm{MHz}, \mathrm{CDCl}_{3}\right) \delta(\mathrm{ppm}):-2.63(\mathrm{br}, 2 \mathrm{H}, \mathrm{NH}), 7.40(\mathrm{t}, 8 \mathrm{H}, J=7.2 \mathrm{~Hz} \mathrm{~Hz}, \mathrm{Ar}), 7.51(\mathrm{t}, 16 \mathrm{H}$, $J=7.5 \mathrm{~Hz}, \mathrm{Ar}$ ), 7.93 (d, 16H, J=7.5 Hz, Ar), 8.26 (s, 4H, Ar), 8.50 (s, 8H, Ar), 9.06 (s, 8H, Py). ${ }^{13} \mathrm{C} \mathrm{NMR}\left(75 \mathrm{MHz}, \mathrm{CDCl}_{3}\right) \delta(\mathrm{ppm}): 100.0$ (Ar), $121.1(\mathrm{Ar}), 125.4$ (Ar), 127.7 (Ar), 129.0 (Py), 132.7 (Ar), 138.5 (Ar), 140.1 (Ar), 140.9 (Aripso), 143.1 (Aripso), 163.2 (Aripso). MS (MALDI-TOF) m/z: 1222.3. Anal. Elem. calc. for: $\mathrm{C}_{92} \mathrm{H}_{62} \mathrm{~N}_{4}$. C 90.31, H 5.11, N $4.58 \%$. Found: C 90.33, H 5.10, N $4.59 \%$.

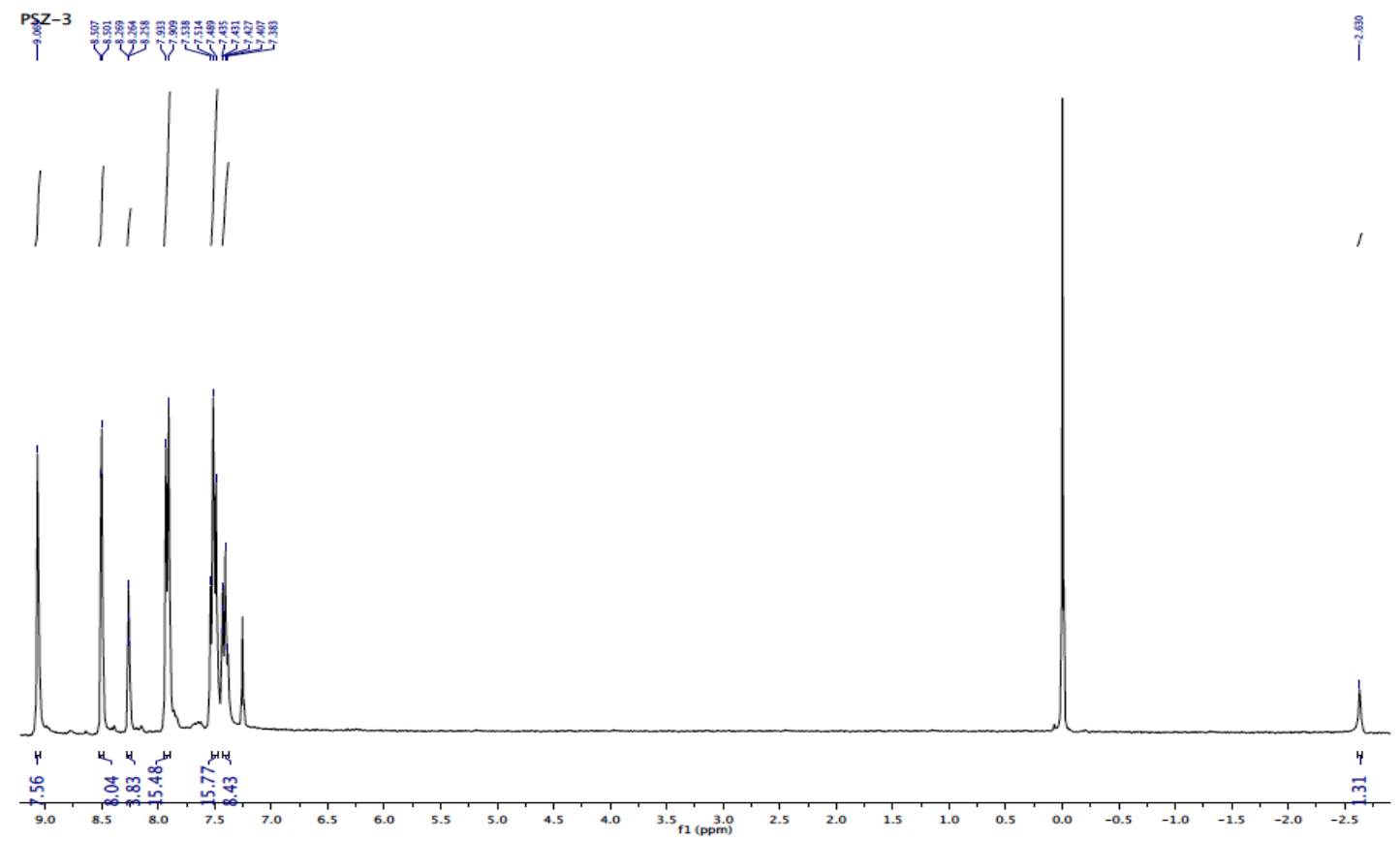

Figure 10. ${ }^{1} \mathrm{H}$ NMR for porphyrin 9. 


\section{Porphyrin 10.}

Purple solid. Yield $174 \mathrm{mg}(0.13 \mathrm{mmol}) 30 \%$. UV-Vis $\mathrm{CHCl}_{3}(\mathrm{~nm}): 650,590,550$, 515, 420, 400, 270. IR KBr (cm $\left.{ }^{-1}\right): 3286,3030,2921,2852,1662,1588,1560,1511,1448$, 1409, 1366, 1263, 1224, 1172, 1106, 1014, 976, 906, 817, 726, 700, 606, 559, 524, 493. ${ }^{1} \mathrm{H}$ NMR $\left(75 \mathrm{MHz}, \mathrm{CDCl}_{3}, \mathrm{CD}_{3} \mathrm{OD}\right) \delta(\mathrm{ppm}):-2.58(\mathrm{~s}, 2 \mathrm{H}, \mathrm{NH}), 6.86(\mathrm{~d}, 16 \mathrm{H}, J=8.7 \mathrm{~Hz}, \mathrm{Ar})$, 7.76 (d, 16H, J=8.7 Hz, Ar), 8.17 (s, 4H, Ar), 8.42 (d, 8H, J=17.4 Hz, Ar), 9.03 (s, 8H, Py), ${ }^{13} \mathrm{C} \mathrm{NMR}\left(75 \mathrm{MHz}, \mathrm{CDCl}_{3}, \mathrm{CD}_{3} \mathrm{OD}\right) \delta$ (ppm): 100.0 (Ar), 115.1 (Ar), 128.3 (Py), 115.6 (Ar), 131.1 (Ar), 131.6 (Ar), 131.9 (Ar ipso $_{\text {) }} 139.9$ (Aripso), 147.9 (Aripso), 157.6 (Ar-OH), MS (MALDI-TOF) m/z: 1350.1 Anal. Elem. calc. for: $\mathrm{C}_{92} \mathrm{H}_{62} \mathrm{~N}_{4} \mathrm{O}_{8}$. C 81.76, H 4.62, N=4.15 \%. Found: C 81.74, $\mathrm{H} 4.60, \mathrm{~N}=4.17 \%$.

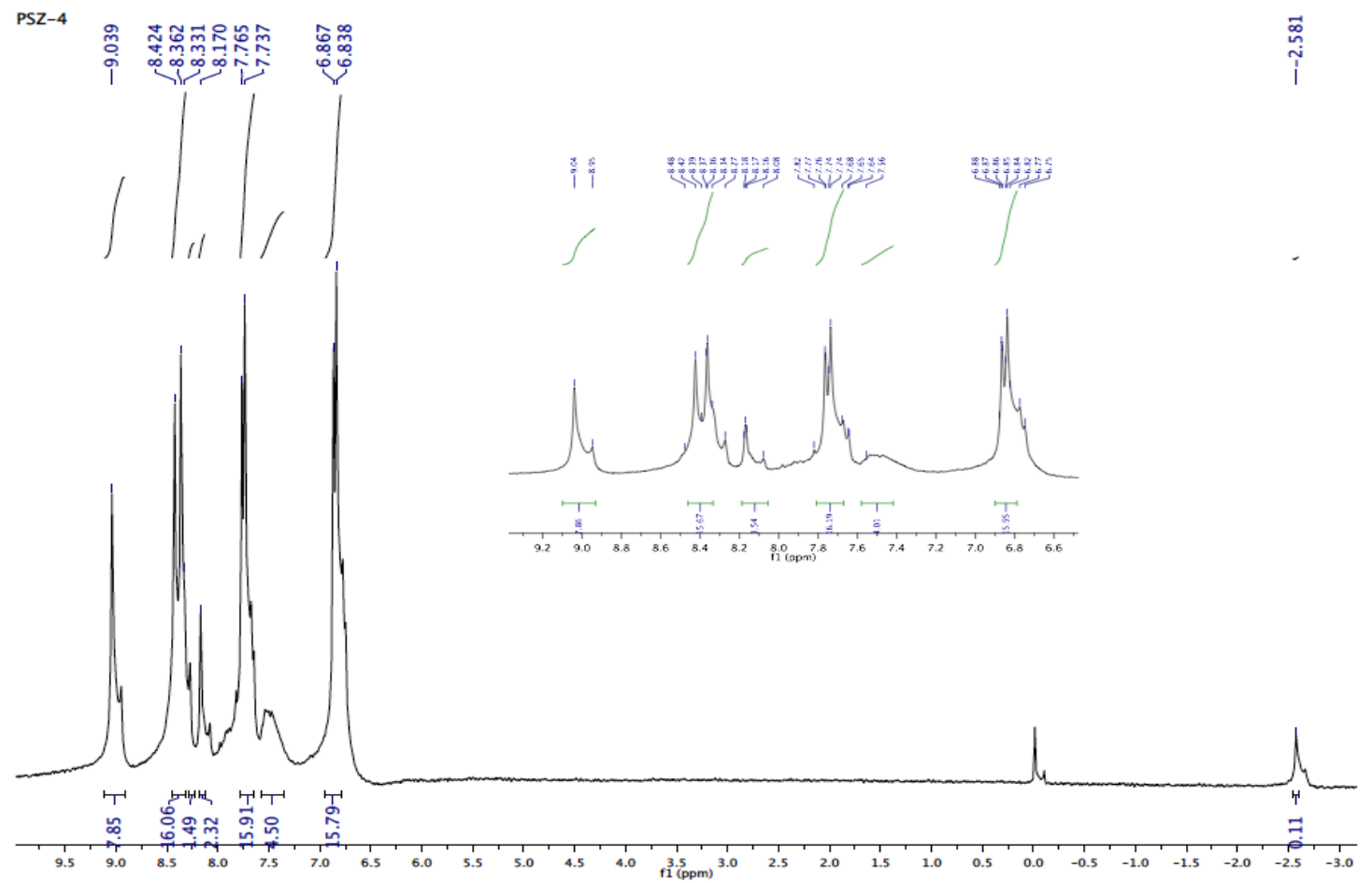

Figure 11. ${ }^{1} \mathrm{H}$ NMR for porphyrin 10. 